\title{
THE VALUE OF THE "FREEDOM" CATEGORY IN THE CONTEXT OF THE PROBLEM LEGAL CULTURE
}

\section{Protosavitska L. S.}

\section{INTRODUCTION}

In the process of building a democratic state governed by the rule of law, such principles as the principle of freedom of man and citizen must be ensured and guaranteed.

Human freedom and responsibility for their actions are a prerequisite for the existence of natural rights of the individual. The study of the problem of freedom is of great practical importance in assessing the activities of individuals. This is of great moral importance. Neither morality nor law can ignore this problem. Without the recognition of human freedom can not talk about his moral and legal responsibility for their actions. If people don't have freedom, the question of their responsibility for their behavior becomes meaningless. Freedom, free choice, inner harmony - this is a necessary condition for a harmonious meaning of life, both for the individual and for society as a whole. Therefore, freedom is a formal condition only.

Freedom must be accompanied by an attraction to certain values, so that the meaning of life becomes a reality. Only when a person consciously chooses and affirms certain values for himself, his life becomes meaningful. Human life has meaning as long as the values it embodies are acceptable to people and recognized by society. We can state that values, along with freedom, make up the meaning of human life. Freedom is a fundamental legal value. The source of freedom is the nature of man as a person capable of making his choice and being responsible for its consequences, to determine their goals and means of achieving them.

Values perform complex and versatile regulatory functions in relation to society, the individual, and its freedom. Therefore, the study of values is directly related to the need to understand the national, cultural and legal identity of Ukraine. Also to determine its place in the global development of civilization, to clarify its unique status and prospects for further development ${ }^{1}$.

The study of values requires a comprehensive analysis of their content, which is mediated by their civilizational features.

\footnotetext{
${ }^{1}$ Kachur, V., Protosavitska, L., Zasukha, L., Golovko L. The Role of Legal Culture in Maintaining Social Stability and Countering Separatist Movements: Case of Ukraine. European Journal of sustainable development, 2020. Volume 9, № 1, 294-299.
} 
Legal culture is one of the conditions for sustainable development of Ukrainian society. This will make it possible to rethink the role and importance of state and legal institutions to ensure the preservation and development of the state both at the everyday and scientific level ${ }^{2}$.

Legal culture is a kind of general culture and embodies the synthesis of law and culture. Therefore, we propose to define legal culture as a specific way of organizing and developing the legal life of participants in public life in specific historical conditions, which determines the legal orientation and legal position of the subject and is manifested in legal values ${ }^{3}$.

Freedom is one of the key values in ensuring and guaranteeing territorial integrity. Freedom is the most difficult category in both philosophy and law. It defines the essence of the individual, which includes the ability to think and the ability to act in accordance with their intentions.

In addition, it includes desires and interests. Many scientists and thinkers have addressed the problem of freedom.

The concept of freedom is historically variable. The problems of freedom were solved perfectly in different periods of history. For primitive man, freedom primarily meant belonging to a family, and the loss of contact with this tribe was tantamount to death. For a person living in the industrial and post-industrial era, freedom is an opportunity to dispose of their personality, activities, property, means of production, as well as create them. In this case, freedom acquires legal and economic meaning.

Freedom is characterized by internal contradiction, ambivalence. Freedom as a choice plays the same role in social progress - as natural selection and in biological evolution. This form of freedom makes a person not a passive object of evolution, but an active participant in social development. On the other hand, freedom carries the threat of the disintegration of society and is unacceptable to it. Freedom carries out various transformations - qualitative changes, modifications, as history shows. Most categories of philosophy originated in antiquity, so it is necessary to begin the study of the idea of freedom from this period.

\section{Freedom as a value in the philosophical and legal heritage of human civilization}

Thinkers and scientists have studied the problem of freedom throughout the historical development of human civilization. Ancient scientists were the first to address the problem of freedom.

${ }^{2}$ Качур В. Протосавіцька Л. (2020) Місце категорії «цінність» у теорії правової культури Modern achievements of EU countries and Ukraine in the area of law : Collective monograph. Riga : Izdevniecība "Baltija Publishing”, 2020. P. 1.632 p. P. 225.

3 Качур В.О. До визначення поняття «правова культура» у правознавстві. Право. Людина. Довкілля: науково-практичний журнал. 2019. № 10(1). С. 17-18. DOI: http://dx.doi.org/10.31548/law2019.01.002. 
The real status of freedom of some is provided by the slavery of others, namely in antiquity. Ancient law is characterized by the position of a free man and the position of a slave. The concept of freedom includes various limitations in the modern world. We state that the freedom of one person is determined by the freedom of another person, the limits of which are determined by law ${ }^{4}$.

The problem of freedom was solved ambiguously in ancient society. The way of thinking of the ancient Greeks and Romans before the advent of Plato was aimed at understanding concepts such as "necessity", "fate" or "chance".

This is due to the prevailing idea in the society of that time about the universe, where everything has its place and performs a clear function that does not depend even on the will of Zeus. Zeus was not in control of the lot, fate. Moira wove the threads of destiny and none of the gods could change destiny.

Blind belief in destiny leads a person to lose a sense of responsibility for their actions.

The concept of such a function will be expressed in the category of destiny, which was taken as a necessity. In the term "fate" invested the solution of the individual problems of the relationship of freedom and causality, necessity or chance, external and internal. However, the appearance of the image of fate in human consciousness has provided contrasting man and the world, the subject of knowledge and freedom - object. There was a temptation to transgress beyond law and order, the idea of struggle arose, eventually.

Fatalism was characteristic of Greek myths. This means that events in human life and society are determined by fate. The implementation of certain events in the future is inevitable, so that a person does not act against his destiny.

So the end result is revealed to the person in advance. Therefore, the preceding reasons are not important at all and may even have many options (when no one is trying to avoid fate).

However, determinism also took place in ancient Greek society. The essence of which was that any events occur in accordance with the cause-and-effect relationship. Determinism is based on the doctrine that any events occur according to natural laws and are related to causal processes. Determinism leaves no room for variance or chance.

Heraclitus was the first to apply determinism to his scientist. He argued that extremes (opposites) are constantly passing into each other.

Atomists Leucippus and Democritus argued that there is no place for chance and freedom in the world. Leucippus argued that nothing in the world arises for no reason, that everything has a cause by some necessity.

Democritus denied the possibility of accidental events. This is a strict conditionality of events. The Stoics were determinists. Everything that happens in the universe or in human life is strictly due to previous reasons. Coincidence is impossible.

${ }^{4}$ Гуторович О.В. Проблема свободы и её решение в античной философии. URL: https://www.gramota.net/articles/issn_1997-292X_2015_7-1_09.pdf C. 36. 
The person can do nothing against his destiny, outlined providence. The person must be free inwardly. Stoicism relied on the voluntary deprivation of life in order to prove the seriousness of moral freedom. So Zeno, Cleanphus, Eratosthenes, Antipartus and other Stoics committed suicide.

We can see a well-formed idea of the strict dependence of human transgressions on his will in the early Greek works. According to the ancient Greeks, freedom depended on fate, year, fate. Even pagan Slavic mythology was characterized by a «love of fate, the year' a belief in the inevitability of fate.

In the Primary Chronicle it is written that the Prophet Oleg will die from his own horse. This happened as predicted by the soothsayer for the prince.

We note that the views of the Sophists and Socrates on the notion of freedom will change in the future. Socrates was the first genius to bring with him the concept of freedom in Greek science. Socrates tried to learn about nature. He also sought to know man as part of this nature.

Fate has ceased to weigh on man, in his philosophy. She also ceased to be responsible for human actions. Socrates began to consider a person as an independent entity.

Reflections on humanity led Socrates to believe that man could be free. Socrates came to the conclusion that man can be free after thinking about humanity. Socrates said that freedom is ejgkravteia. We are talking about inner freedom. Such freedom is possible in any situation under any circumstances. It involves self-control, the possibility of unimpeded self-determination, domination over physical instincts. Freedom is ejgkravteia, or self-control, domination over physical instincts. Socrates believed that just as God does not need anything and a free man aspires to the same, and his physical needs are minimal ${ }^{5}$.

This kind of freedom is defined in the intellectual abilities of a person. In this way a person can comprehend the world around him, discover the sphere of knowledge. The free essence of man is filled with moral behavior and reason for Socrates. This is close to the Christian understanding of the essence of a person ${ }^{6}$.

The Greek scholar-thinker Plato understood freedom not from a philosophical understanding of the concept of freedom, but from the sociopolitical aspect of this concept. The scientist argued that there is freedom in the world and it is the freedom of self-determination, which involves choosing one»s own path. The choice can be varied.

According to Plato, the final choice belongs to man, and in this choice man is free. He tells in the mythical story of the Era ("State") about the afterlife, in which the souls of the dead themselves determine their future existence. The choice can be varied. A person has the opportunity to link his future social status with the life of a poor or rich person, a king or a beggar, even an animal.

${ }^{5}$ Прохоров К. Тайна предопределения URL: https://royallib.com/book/prohorov_ konstantin/tayna_predopredeleniya.html.

${ }^{6}$ Там само. 
Therefore, the thinker believed that the final choice is up to the person, so he is free in his choice. Plato was convinced that absolute freedom does not exist, because her choice is due to her past life. Therefore, the quality of choice is determined by the presence of a person's true knowledge of wisdom, which he acquired during his life.

In Plato»s work "Menexen" we are talking about equality of origin and personal prowess. Plato draws attention to two features of the rulers - valor and wisdom in this work. We meet with the idea of personal individual freedom in this work. Plato emphasizes that individual freedom is determined by the socio-political environment. The thinker convinced that human freedom is brought up in a free public environment. Therefore, it is the case of a free person to sacrifice his life to preserve this environment ${ }^{7}$

In the work "Phaedo" we are talking about the immortality of the soul. Plato is considered the author of this work. According to Plato, Socrates distinguished between moderation, justice, courage and truth, and freedom. Freedom acts as one of the most worthy socio-political virtues in this case. Plato pointed out that the state has not only its own interests but also its own freedom. Such theses were presented in the work "State".

This is freedom both from other states and from individuals. The scientist points out that the freedom of the state must be properly protected. Warriors are a special stratum, a separate state that must be created for this purpose in the state. The main task of soldiers is to protect the freedom of the state.

This stratum must have certain virtues such as courage, prudence and freedom, according to the thinker. Thus, Plato argued that the state should be free, that is, have freedom. Such freedom of the state can be achieved under the condition of freedom of individuals.

That is, the state that protects such freedom. The concept of political freedom is not limited to individual freedom, according to Plato. Absolutization is an actual absolute monarchy and absolute democracy. This is the freedom of the state in the first case. This is the freedom of the individual in the second case. The normal coexistence of the state and the individual is a certain mutual restriction of their freedoms ${ }^{8}$.

The main goal of a person is not freedom, but service to the state. Therefore, poets are expelled from the Platonic state, because their poems weaken the purposeful devotion to the state. Plato proposed to edit Homer's poems in such a way as to leave in them only episodes that highlight the stability and endurance.

Plato pondered the question: does man need freedom, when he studied the question of freedom. Plato made a similar statement of the problem of

Kiselyov S.O. The problem of freedom in Plato's legacy. URL: http://ekmair.ukma.edu.ua/bitstream/handle/123456789/6126/Kysel\%27ov_Proble ma_svobody_u_spadshchyni_Platona.PDF

${ }^{8}$ Гуторович О.В. Проблема свободы и её решение в античной философии. URL: https://www.gramota.net/articles/issn_1997-292X_2015_7-1_09.pdf C. 36. 
freedom - "freedom for", positive freedom, for the first time in the history of philosophy. This means the focus of human efforts on the realization of their essential forces, on creative creation, on achieving the highest goal. The thinker came to the conclusion that such freedom is dangerous to man and can harm him. He pointed out that it is human nature to abuse freedom. It can be a source of destructive power, so it is better to treat freedom as the prerogative of the state ${ }^{9}$.

Aristotle held a similar view. He was convinced that a person making his choice is primarily guided not by reason but by his ambitions. This manifests both the freedom of man and the imperfection of his nature. Therefore, such freedom is not positive. According to Aristotle, all events can be divided into "necessary" and "accidental".

He argued that in life we often face the vagaries of fate, we observe the dependence of events on external conditions. Aristotle argued that chance is a real fact in the work "Metaphysics". Random events underlie the implementation of the necessary time.

The philosopher drew attention to the will of man when analyzing the circumstances affecting human life. Own life position, the presence of activity allow us to divide human actions into two types - voluntary and involuntary ("Nicomachean Ethics", Book III).

Aristotle was convinced that people can be independent, and this is what allows them to make conscious choices ("proaivresi"), to take responsible action, to build their happiness. The source of the arbitrary is man himself according to Aristotle. The thinker came close to the Christian understanding of the term "freedom of will" in this inference ${ }^{10}$.

The school of cynics "surpassed" all its great predecessors in solving the problem of freedom. This school was one of the famous Socratic philosophical schools. For them, freedom borders on arbitrariness and presupposes the absence of obstacles in the manifestation of their desires.

Freedom cannot be limited by the state, marital relations, decency. Freedom (ajnaivdeia) is a destructive element, in their understanding most likely. Society condemns such freedom in general. Therefore, the personal charm of Diogenes keeps most critics from unequivocally negative assessments of cynicism.

Epicurus (another ancient Greek thinker) was convinced that the world is constantly faced with manifestations of freedom. He described the effect of "repulsion of atoms" when he studied the world of nature. His naturalphilosophical doctrine substantiates the existence of chance, both in the natural state and in the world of people. He argued that "The human soul is made up of atoms whose motion cannot be predicted. Therefore a person can be independent - to make decisions, to make free choices ${ }^{11}$ ".

\footnotetext{
${ }^{9}$ Там само С. 36.

${ }^{10}$ Там само. С. 37.

${ }^{11}$ Словарь античности/пер. с нем. М. : Прогресс, 1989. С. 660.
} 
The Stoics were convinced that human freedom is an internal freedom. Its condition must be awareness of the inevitability of fate. Epictetus (a representative of this philosophical school) argued that the phrase "free man" could be used without expecting anything that came to mind. "Free people must learn and want to agree with everything that was happening to him according to the will of Him who controls the universe" ${ }^{12}$.

Representatives of Roman legal and philosophical thought borrowed the ancient Greek concept of destiny, and even to some extent strengthened it. In the Aeneid, Virgil describes only one active force - rock, with which the Olympian gods oppose. Aeneas has an even more passive attitude to fate than the Greeks. The Stoics glorified the idea of conscious submission to fate, and therefore it became the official philosophy of the Roman Empire.

Eastern religious and philosophical thought could not get around the eternal and universal question of necessity and freedom as well. We find two sides in Hinduism and Buddhism. Namely, on the one hand, in the concept of karma, and on the other hand - the germ of the doctrine of free will (a person is able to take the path of salvation and rebirth avoid new intellectual and volitional effort).

As for Christianity, there have been many theologians in the history of the church who have either denied God's authority over the world and man, or the free will of the latter. Person must acknowledge that he cannot fully comprehend the essence of heavenly things, theologians have argued.

The moral side runs through the whole Bible, which determines the duality of human free will. The Bible testifies that people have free choice. Thus the book of Isaiah mentions that the children of Israel did evil in the sight of the Lord. So they had freedom, they were free to do so.

However, they were powerless to change anything if the Lord punished them by condemning them to the sword (destruction).

Philo of Alexandria - a famous philosopher of the first century. B.C. He saw human freedom as part of the divine plan, an area in which the Lord does not act under duress.

In the eleventh and twelfth centuries, Judas Galevi argued that God is the primary cause of all things, and the secondary cause is the direct causes of everything else, such as the will of man.

The New Testament says that only the Son of God, Jesus Christ, can make people truly free. If the Son "liberates" you, you will be truly free (John 8:36).

Early Christian writings mention the existence of two paths where a person has the right to choose any of them. Every intelligent soul has freedom of will and decision according to Christian thinkers

People don't have the compulsive need to do good or evil against their will. John Chrysostom wrote the work "On Fate and Conduct", where he

${ }^{12}$ Прохоров К. Тайна предопределения. URL: https://royallib.com/book/prohorov_ konstantin/tayna_predopredeleniya.html. 
defended freedom of will and pointed out that God gave freedom of choice "If you want" and "If you do not want".

Augustine the Blessed (a famous representative of the Catholic Church) sowed the seeds of discord in the Christian Church. He argued that all people - sinners, all equally deserving of eternal death. The saved are saved only by the grace of God, according to His unconditional will. Not saved have no right to complain, because they deserved their sinfulness to death. Unbaptized babies who go to hell are a question that evokes unnecessary emotions, so they didn»t talk about it ${ }^{13}$

During the Middle Ages, scholars Anselm of Canterbury, Albert the Great, and Thomas Aquinas viewed the notion of freedom only as freedom of mind and action within the framework of Christian dogma. ${ }^{14}$.

Thus Anselm of Canterbury argued that man, even after the fall, has sufficient freedom to do good deeds without the special help of God. Salvation is impossible without the grace and will of God. Anselm finds an interesting argument: "If an event happens unnecessarily, then God, Who knows in advance" any event of the future, knows it. So he tried to reconcile both doctrines. So something needs to happen unnecessarily".

Bernard Clairvaux was a supporter of free will. Bernard distinguishes three degrees of human freedom: from sin, from suffering, from necessity. Thus, persona has lost the first two kinds of freedom as a result of the Fall, the last freedom is preserved, is the very essence of arbitrariness.

Thomas Aquinas, was a supporter of Aristotle. He argued that achieving good is the goal of human action. Achieving the goal is a large number of options - it is essentially freedom of will and choice ${ }^{15}$

The Thomists (who followed the teachings of Thomas Aquinas) were convinced that God was actively leading some people to salvation according to His will. And allows others to be in their sinful state, as a result of which they perish forever. Representatives of the Eastern Church, in particular John Ladder, argued that any $\sin$ is a manifestation of distorted freedom, a spiritual suicide. A monastic feat is freedom addressed to the Lord, true freedom of will. Maximus Confessor argued that any freedom of human choice testifies and reminds people of their sinfulness and imperfection.

Human freedom is indecision before our ascension to God and reunion with Him. True freedom is revealed in God, but it is not violent in relation to the perverted and imperfect sin. However, with the help of grace, capable of self-determination, the will of $\operatorname{man}^{16}$.

${ }^{13}$ Прохоров К. Тайна предопределения. URL: https://royallib.com/book/prohorov_ konstantin/tayna_predopredeleniya.html.

${ }^{14}$ Там само.

${ }_{16}^{15}$ Христианство. Энциклопедический словарь. В 3-х тт. М., 1993-1995. Т. 2., с. 523.

16 Лосский В. Очерк мистического богословия Восточной Церкви. В кн.: Мистическое богословие. Киев,1991. С. 176. 
Representatives of the Eastern Church maintained that God is independent in the light of His holiness and justice. The God's relationship with man is built on a gracious and trusting foundation.

He has infinite time to educate and motivate every sinner. And only those people will perish forever who will reject such great mercy of God, after being given many opportunities for reconciliation. True freedom always implies both the answer "yes" and "no", unfortunately.

In the Reformation era there was a return to the Augustinian concept of predetermination of all events and actions and the denial of real human freedom $^{17}$.

The Renaissance was characterized by the restoration of ancient ideas about fate, with its return to antiquity. Niccolo Machiavelli proposed a kind of solution to the problem, namely: "fortune is changeable, like a woman.

Whoever wants to subdue her, or at least deal with her, must behave energetically and defiantly (to the point of "beating" her!), As if he wants to win the affection of a capricious beauty". Machiavelli pointed out that otherwise, nothing can be achieved in this matter.

Zwingli (Reformation Representative) argued that man's existence of real freedom called into question the existence of an almighty God. Erasmus Rotterdam paid tribute to free will, without denying God's supremacy over all things. Salvation on one's own is impossible.

Martin Luther supported the view of Blessed Augustine and argued that man is completely corrupted as a result of the Fall. Therefore, all the good that man does is not done by man himself, but by the grace of God, which works in men. Luther deprives the human will of any initiative. God and Satan are fighting for each of the people. Person serves God if he wins. Person immediately begins to sin if God yields to Satan for some reason.

Calvin was convinced that the fall of Adam did not occur by the indulgence of God, but by his doom. Since then, a large number of people are sent by the Almighty to hell. According to Calvin, people should reverently remain silent about such a sovereign decision of God.

St. Orikhovsky is interested in freedom, quite. Orikhovsky considered spiritual freedom to be a great value of earthly life, because it gives him the opportunity to become spiritually perfect and remain in the memory of future generations even after physical death.

One of the prerequisites for spiritual freedom is self-knowledge, which helps a person to achieve inner, spiritual development, moral improvement. He believes that self-knowledge will help to find creative potential, and will contribute to the solution of the main goal of human life - full selfrealization in some sphere of human activity. However, one must study not only oneself, but also study various earthly and celestial phenomena, and be a supporter of education.

17 Прохоров К. Тайна предопределения. URL: https://libking.ru/books/prose-/ prose-rus-classic/249278-konstantin-prohorov-tayna-predopredeleniya.html. 
Freedom and wisdom for Orikhovsky are interconnected, wisdom gives freedom, illuminates the way to it, makes a slave a free man, and a state in which everyone has everything that belongs to him: freedom, relative peace and the ability to fulfill their purpose at will ${ }^{18}$.

Attitudes toward the phenomenon of freedom are changing in the New Age. Thomas Hobbes argued that all our thoughts are not accidental, not involuntary. They are deprived of their freedom and obey strict mental laws - the goals of our thinking and associations. He considered the idea of free will simply absurd.

Hobbes pointed out that freedom in human life can be called only "the absence of external obstacles to movement". The scientist gave an example: if the water of the river flows along a channel in which there are no obstacles, then it is free. This is how a person lives, who wants what is necessary and does as God wants ${ }^{19}$.

Another scientist B. Spinoza pointed out that just as there is no place for chance in the physical world, there is no freedom in the spiritual realm. Spinoza perceived sin, indecent behavior of people - as inevitable intellectual errors and ignorance, following Socrates and Plato.

The scientist pointed out that a person's inability to control or restrain his feelings is called slavery. After all, persona isn't himself a master under their influence, but, on the contrary, is governed by a destiny that has full power over him. Therefore, she is often forced to make worse choices, although clearly better for her" ${ }^{\prime 20}$.

Leibniz gave due place to the free will of man, in his philosophical systemic difference from Spinoza. He argued that God presupposes the existence of evil in the world (as a continuation of human freedom for the perfection of the overall picture of the universe).

German scholar Kant applies a certain dualism, exploring the question of freedom. He argues that as a thinking being and one who tries to comprehend and understand the world, a person has free will.

But a person does not have free will as a being who lives in a physical, causally conditioned world. The moral law laid down by God in everyone requires justice: you must repay good virtuous people and condemn the wicked. Obviously, this is not happening fully on earth. Therefore, God will carry out His just judgment. when the afterlife comes. Person still has real spiritual freedom, because without it morally decent life and virtue are impossible ${ }^{21}$.

Schopenhauer (another German scientist) argued that the will is the basis of both animate and inanimate nature. It reaches its culmination in person.

${ }^{18}$ Майданюк I. Свобода як цінність права у філософській спадщині Станіслава Оріховського. URL: https://ela.kpi.ua/bitstream/123456789/11136/4/08.pdf.

${ }^{19}$ Гоббс Т. Соч. в 2-х тт. М., 1991. т. 2, с. 163, 164.

${ }^{20}$ Спіноза. Етика. URL: http://loveread.ec/read_book.php?id=90717\&p=67\#gl_23 c. 67.

${ }^{21}$ Кант И. Критика чистого разума. СПб.,1993, с. 449-456. 
Schopenhauer sees freedom of will as the freedom of things in themselves, which can not in any way affect the outside world. Each person performs certain acts as needed, due to the peculiarities of his character. He argued that if we knew nature and motives accurately, we could accurately predict human behavior.

In this regard, the scientist gives an example. The water could say, "I can turn into huge high waves!" (Yes, but only during a storm at sea). "I can run away fast!" (But only in the riverbed). "I can fall down noisily!" (Only in the waterfall). "I can go up in the air!" (In the fountain). "I can evaporate!" (But not otherwise than at boiling temperature). "However, now I prefer not to do anything, but to be quiet in the pond ...,22 .

According to the French scientist Sh.-L. Montesquieu, freedom is ambiguous. It can cause many misunderstandings. Freedom was understood as a known necessity as cognition and thinking, the ability to believe in something. Freedom was recognized as a living breath of human selfdevelopment (the process of modifying freedom). Freedom has a cause in itself and has no cause outside itself. Freedom was a special factor that determined the law.

Representatives of neoclassical philosophy went beyond the psychologism and epistemology of freedom. J. Sarthe pointed to both doom and freedom, A. Camus considered freedom as an opportunity for rebellion. M. Scheller understood freedom as a vital phenomenon in philosophy. M. Buber believed that freedom is overcoming alienation in the category of "I-You". G. Marcuse understood freedom as liberation in a space that goes beyond one-dimensionality. Freedom and responsibility of the individual is the basic idea of existentialism, which defines freedom as a fundamental feature of human existence, which allows people to create themselves and choose the future.

People are free, but their freedom is expressed in their attitude to the universe, in choosing their own inner spiritual and moral position. Therefore, people are responsible for their actions only when they have freedom of will, freedom of choice and freedom of means for their implementation. The problem of people's responsibility for their freedom and actions is related to understanding the limits of this freedom ${ }^{23}$.

German scientist M. Riedel emphasizes that the right to freedom has always been inherent in every person who has studied the phenomenon of freedom. It should be understood as independence from domination (unilateral pressure) by a particular class or group ${ }^{24}$.

22 Шопенгауэр А. О свободе воли. Калининград, 2001, с. 255.

23 Бровко Н.I. Філософсько-правовий аналіз категорії свободи та відповідальності людини. Філософські та методологічні проблеми права, № 1.2014 C. 54-57. URL : http://elar.naiau.kiev.ua/jspui/bitstream/123456789/933/1/8.pdf.

${ }^{24}$ Рідель М. Свобода та відповідальність. Два основних поняття комунікативної етики // Ситниченко Л. Першоджерела комунікативної філософії. К., 1996. с.68-84. 
This freedom reveals the reality of responsibility. In modern conditions, a person is "condemned, doomed" not so much to freedom as to take responsibility, without which the struggle for equality and justice may end in the destruction of what contributes to their implementation ${ }^{25}$.

\section{The value of freedom in the context of the problem of legal culture}

The category of freedom is multifaceted and diverse. The range of its interpretations is very wide.

Human rights have always been accompanied by the development and attempts to implement the idea of freedom. After all, the purpose of their creation and implementation in law was to achieve a greater degree of individual freedom. Freedom is a universal value, and its source is human nature, through the prism of inalienable human rights. Therefore, the problem of freedom is very relevant and requires philosophical and legal understanding.

The category of "freedom" should be considered primarily from the standpoint of voluntarism and fatalism. Voluntarism is a term derived from the Latin voluntas - will. Voluntarism is an idealistic trend, where the will is seen as the highest principle of existence.

Modern voluntarism is based on the teachings of Augustine and John Duns Scott. They argued for the superiority of will over intellect. Scholars such as Kant and Fichte have argued the primacy of practical reason in this matter. Voluntarism appears as an independent direction, in the teachings of Schopenhauer. For him, the will is only a blind and unreasonable basis, which dictates its laws to man.

Voluntarism finds expression in activities that are not based on objective laws of historical development, in socio-political practice. It is guided by the subjective desires of the subjects who carry out these activities. If we act in the spirit of voluntarism, it means disregarding historical necessity, the laws of nature and society and pretending to be arbitrary, freedom for the highest wisdom.

In view of this, we can say that voluntarism absolutizes freedom and rejects the need for the history of society and the life of the individual. Giving an example of voluntarism, we can cite the example of political practice from the life of foreign countries and from the life of our country.

We can note that fatalism translated from Latin, means fatal. Fatalists consider the history of mankind and the life of each individual drawn by God's will (theology), drawn by fate (mythology). It is also a relentless connection of causation in the middle of a closed casual system (Spinoza and Hobbes rationalism).

\footnotetext{
25 Петренко М.О. Філософія свободи в контексті проблеми людської гідності. Науковий вісник. Серія «Філософія». Харків : ХНПУ, 2017. Вип. 49. C. $142-156$. C. 151.
} 
In view of the above, we can say that fatalism absolutizes the need for social processes, it rejects freedom of choice. There is an idea of the inevitability of social processes and the impossibility of any changes on the part of a person. Fatalism leads to the emergence of such a feeling as humility before one's own destiny. Thus fatalism condemns man to passivity, refusal to act and obedience. Fatalism was especially practiced in various occult doctrines such as astrology and spiritualism in times of crisis or during the transition from one era to another.

Proponents of Marxism rejected voluntarism and fatalism, considering the concept of freedom. They argued that people don't have the ability to change their living conditions. However, all people have free will in choosing goals and ways to achieve these goals. They emphasized that there are several possibilities for their actions at any given time. In addition, everyone is free to choose the means to achieve their goal. Freedom isn't absolute, but relative.

This freedom is realized by choosing one or another way (plan) of action. The more clearly each person is aware of their own real possibilities, the more means to achieve the goal, the greater the freedom. Marxists believed that this was the objective basis of freedom as a phenomenon of human existence.

Marxists came to the conclusion that the choice of activity is combined with great moral and social responsibility for the consequences of this activity and choice. The real choice differs from arbitrariness in that it is the result of a complex synthesis of objective possibilities of external reality and the subjective richness of the inner world of man, the social experience he has accumulated. This process reveals the true meaning, spiritual and moral wealth of the individual. Free choice is a test of the strength of such components of personality as conscience, dignity, honor, responsibility, and so on ${ }^{26}$.

So, we can say that the choice of personal behavior, one's own path is the result of people's will. Therefore, man can not exist without some self, that without freedom. Freedom (as a conscious choice of human behavior) depends not only on the external environment. It also depends on the spiritual world of people, on the extent of their inner attitude to truth, good and evil, beauty and justice, etc.

Freedom is also expressed in the ability of people to change certain situations, to plan and strive to reach new heights. The concept of freedom is closely linked with human nature, with the historical development of mankind and the formation of civilization. His subjects have had varying degrees of freedom since the beginning of human history.

The generation of rights is seen as a category of degrees of freedom in jurisprudence. The first generation of rights includes the right to life and property. It is expressed as the ability to protect one's own life and livelihood.

26 Данильян О.Г., Тараненко В.М. Основи філософії. Проблема свободи і відповідальності людини. URL: http://library.nlu.edu.ua/POLN_TEXT/4\%20KURS/ 4/1/13H3R13_3.htm. 
The second generation of rights includes socio-economic rights. The third generation of rights is the right to peace, health and the environment. The fourth generation of rights - refers to the transition between life and death as the basic values of mankind (abortion, euthanasia) ${ }^{27}$.

People's ability to freedom is manifested in the fact that they, completely unaware of it, choose and approve of their decisions. Even what is given once and for all by the uncertain course of events and does not seem to require any subjective support. But the essence of any human choice is an action that becomes possible on its basis.

Complete freedom requires a conscious attitude of human subjectivity to one's own will, the ability to reconcile it with universal values and norms of non-discriminatory communication. Two important moments of true human freedom are the mastery of external reality and moral control over oneself ${ }^{28}$.

The word freedom can be understood in several senses. Very often, along with the category of "freedom" use the concept of "responsibility". Responsibility (in this case) is both a social and philosophical concept that reflects the objective-historical nature of the relationship between the individual and society. It is also manifested between the individual and the social group, which were formed in the course of satisfying mutual requirements.

We can distinguish between political, legal (legal), moral responsibility. And all this depends on the sphere of activity and individual, group, collective, which depends on the subject of the respective actions. Responsibility can be formed as a result of the requirements that society, social group, team imposes on the individual. They become the basis for motivating her behavior in the process of assimilation by the individual. Personality is formed in the process of education. A sense of responsibility is formed as the main feature of personality in the process of education.

An important issue for understanding the relationship between freedom and responsibility is to determine the limits of human freedom. Freedom and responsibility are inseparable concepts. Freedom is impossible without responsibility. Responsibility is the inevitable price of freedom, the price for it.

Freedom is a fundamental human value, but it must have its limits and limits. It should not become arbitrariness, violence against other people, that is, it should not turn into captivity. In view of this, we note that the limits of freedom are the interests of another person, social groups and society as a whole. The same applies to nature as the natural basis of society.

The freedom of the individual is limited by the interests of this society, in any society. However, the desires and interests of members of a society do not always coincide with the interests of that society. In this case, the

27 Філософія права : підруч. для студ. юрид. вищ. навч. закл / Свобода як цінність. Право як форма свободи. URL: https://fil.wikireading.ru/52706.

28 Ситниченко Л.А. Стратегії свободи в сучасній соціальній та практичній філософії. Свобода: сучасні виміри та альтернативи. К.: Укр. Центр духовн. культури, 2004. С. 137-145. 
individual is forced to act that does not violate the interests of society. This is done under the influence of the laws of society.

The growth of the degree of freedom of the individual can be a criterion of social progress. The possibility of free choice of the individual was different at different stages of human history. New opportunities open up for the growth of the degree of individual freedom in the development of society, with each new era. This position has become generally accepted modern social science, both in the West and in the East.

Therefore, today the main criterion of social progress is the level of humanization of society, the position of the individual in it - the level of its economic, political, social and spiritual freedom. Every social formation or civilization is progressive insofar as they expand the range of rights and freedoms of the individual, creating conditions for his self-realization.

However, it should not be forgotten that freedom can only be a criterion for social progress when its growth is within reasonable limits. When these limits at any stage of development of society is the responsibility of the individual to society, and going beyond the permitted limits is the cause of anarchy, and this is incompatible with the concept of "freedom". Montesquieu said that the idea of freedom is ambiguous, and it can cause many misunderstandings.

We also want to separate "actual" freedom from "legal" freedom, talking about freedom. Conditionally, freedom is divided into "external" and "internal". Freedom is also divided into freedom "from" (negative freedom) and freedom "for" (positive freedom). Legal freedom is a permission to commit certain actions. Legal freedom includes freedom of choice. Actual freedom means "what I want, I do".

Freedom includes freedom of choice as the very fact of choice, as well as unpredictability as such. Situations of choice aren't freedom as such, but only a prerequisite for free action ${ }^{29}$.

"Inner freedom" is a real freedom in the sense of freeing a person from the shackles of their personal stereotypes and inner fears. "External freedom" allows the search for limited means and forms of restriction. Hegel (German scientist) argued that when a person has no idea of his own freedom, he does not imagine the freedom of others and the connection between these freedoms.

The individual has a certain area of choice of ideas without the possibility of encountering restrictions and repression - in freedom "from" (negative freedom). Freedom "for" is a positive freedom. It makes it impossible to act in accordance with one's own system of values and one's own goals. People are able to give up freedom in favor of authoritarian rule in order to increase the possibility of achieving their own goals. However,

29 Філософія права : підруч. для студ. юрид. вищ. навч. закл. Свобода як цінність. Право як форма свободи. URL: https:/fil.wikireading.ru/52706. 
this applies to certain conditions when people have a significant degree of freedom.

This is a kind of replacement of the theoretically possible and practically feasible. Because positive freedom is paramount, real forms of escape from freedom are rare $^{30}$.

M. Popovych claims that in fact there is no "freedom from" and "freedom for" as different social values - there is the same freedom seen and felt either inside ("for") or outside ("from") ${ }^{31}$.

Z. Bauman emphasizes the intersubjectivity of the nature of freedom and considers it as a social relationship to overcome this dilemma. Bauman enshrines the intersubjectivity of the nature of freedom and considers it as a social relationship. He also points out that "the freedom of some makes both the dependence of others necessary and profitable, while the lack of freedom of one part makes possible the freedom of another" ${ }^{32}$.

Based on the above, we can state that life in modern society requires further study of the problems of freedom. However, we should agree with the view that "awareness of this problem has developed only in the context of the accumulation of new and new definitions". This applies to the fact that "it is possible to observe a certain kinship and attraction of the ideas of freedom to some related theoretical achievements, which have already received general recognition" 33 .

Often people can not change the conditions of their lives, but they are somehow free to choose the means to achieve this goal. Accordingly, freedom is an inalienable value and is realized through the choice of one or another act. Therefore, the choice of means must be combined with moral and social responsibility for the consequences of this choice in order to achieve the goal. Therefore, the real choice is the result of a complex combination of objective possibilities and subjective richness of the inner world of man, his social experience.

Therefore, only the free choice of means is a test for such components of the human personality as honor, conscience, responsibility, competence, dignity, etc. It should also be noted that "only truly honest people are able to voluntarily define human rights and responsibilities." Limits of their will and its application (criterion of responsibility)".

${ }^{30}$ Там само.

31 Попович М.В. «Свобода від» і «свобода для» Проблеми сутності свободи: методологічні та соціальні виміри. Матеріали Науково-теоретичної конференції 26 жовтня 2007 року. К., 2007. С. 3-8. С. 4.

32 Петренко М.О. Філософія свободи в контексті проблеми людської гідності. Науковий вісник. Серія “Філософія”. Харків : ХНПУ, 2017. Вип. 49 С. 152.

33 Лях В. Соціальні, особистісні та екзистенційні виміри свободи. Мультиверсум. Філософський альманах. К., 2004. № 44. С. 1. 


\section{Freedom as a value of the rule of law}

In the process of building a democratic state governed by the rule of law, such principles as the principle of freedom of man and citizen must be ensured and guaranteed.

Freedom is the highest value. It turns goods into the property of those who acquired them. Freedom requires that the individual be able to pursue his own goals. However, an individual can pursue his own goals only by defining property rights and the areas in which he has the right to dispose of resources. Therefore, the volume and nature of property establishes the real area of his free action.

Any study of freedom is impossible without a study of the principle of equality. Freedom and equality are two interrelated categories that characterize law. Thus, according to Article 1 of the Universal Declaration of Human Rights, "All human beings are born free and equal in dignity and rights", and Article 3 of the same Declaration states that "Everyone has the right to life, liberty and security of person" ${ }^{34}$.

It is worth noting that the provisions of the Universal Declaration of Human Rights have formed the basis of many regulations. This confirms the importance and inalienability of the principle of freedom for the rule of law and civil society.

Having analyzed various international acts and constitutions of foreign countries, we note that the legal consolidation of freedom can be expressed in the following provisions: First, the limits of freedom can be determined only by law, which is a measure of freedom; Secondly, all people are equal from birth and no one has the right to alienate their natural rights, that is, all are equally free. Third, human freedom cannot be absolute, it is limited by the rights and freedoms of others, the principles of morality.

We understand freedom, in a broad sense, the meaning of the term freedom - the natural state of the people and the individual who has the opportunity to act on their own. Freedom is a subjective ability of a person and a citizen to commit or not to commit specific actions based on constitutional rights and freedoms, in the narrow sense ${ }^{35}$.

The principle of freedom, equality and justice belongs to the highest legal values in the axiological sense. Among them, the main and determining factor is the principle of freedom. Every individual must first and foremost be socially free. Only a free person can claim formal equality with another free person ${ }^{36}$.

Legal guarantee of freedom in the constitutions of countries previously under totalitarian influence is carried out by recognizing freedom as the goal

34 Загальна Декларація прав людини : ООН; Декларація, Міжнародний документ від 10.12.1948 p. URL : http://zakon2.rada.gov.ua

${ }^{35}$ Конституционное право зарубежных стран : учеб. для вузов / под общ. ред. М. В. Баглая, Ю. И. Лейбо, Л. М. Энтина. 2-е изд., перераб. М. : Норма, 2004. 832 c. C. 105.

${ }^{36}$ Мальцев В. А. Право как нормативно-деятельная система. Изд. вузов. Правоведение. 2003. № 2. 180 с. С. 19. 
of political activity of the state, declaring freedom the highest social value, consolidating freedom as a legal concept (category), fixing numerous constitutional rights.

In the French Declaration of the Rights of Man and of the Citizen of 1789 , freedom is defined as the ability to do anything that does not harm others. In view of this, the exercise of individual rights has only those limits that ensure that other categories of society enjoy the same rights.

For example, the declaration states that ensuring natural and inalienable human rights is the goal of any political union. These rights are freedom, property and security. They can be limited only by the state with the help of the law only in relation to acts that are harmful to society. In view of this, the axiom follows: "Everything that is not prohibited by law is permissible, and no one can be forced to do what is not provided by law." Also, we can cite Article 31 of the Constitution of the Republic of Poland, which states that human freedom is subject to legal protection. Everyone is obliged to respect the freedoms and rights of others. No one may be compelled to do what's right does not oblige him to do.

Restrictions on the exercise of constitutional freedoms and rights may be established only by law and only when they are necessary in a democratic state for its security or public order or for the protection of the environment, health and public morals or the freedoms and rights of others. These restrictions may not contradict the essence of freedoms and rights, no one may be forced to do what is not required by law ${ }^{37}$.

The constitutions of other states state that everyone has the right to liberty (Constitution of Hungary (1990) - Article 55; Constitution of the Republic of Uzbekistan (1991) - Article 24. Constitution of the Republic of Bulgaria (1991) - Article 30.

The Constitution of Lithuania (1992) guarantees the right of a person to live freely on the land of his ancestors - the preamble of the constitution. Constitution of Italy (1947) - freedom of the individual is inviolable Article 13 of the Constitution of Italy. The Constitution of France (1958) states that no one may be unjustifiably deprived of his liberty - Article 66 of the Constitution of France.

Freedom is freedom, and if you accept this statement, then everything else follows automatically. So you can not partially give up freedom, because in this case, freedom is lost completely.

$\mathrm{R}$. Rayek. argued that freedom is integral and indivisible. Restriction of freedom, in any aspect, leads to the expansion of power, its impact on the lives of individuals in society, to a decrease in personal freedom, to stagnation and ultimately to totalitarianism. In view of this, it should be noted that no restriction, even if it is aimed at the common good, can help to consolidate or expand the personal freedom of the individual.

37 Конституція Польської республіки від 2 квітня 1997. URL: https://www.concourt.am/armenian/legal_resources/world_constitutions/constit/poland/po land-r.htm. 
In general, the main threat to personal freedom is the state. It is the state, covering its actions with the public good, with the help of the authorities trying to establish control over all spheres of public life, which leads to restrictions on human freedom. So, freedom is really the highest social value.

Freedom is provided and guaranteed by the state. The measure of freedom is manifested only in existing law. The law determines the position and role of the individual in society. In this sense, the measure of human freedom is a legal law.

The consolidation of freedom, as the goals of the state and society in modern constitutions, is the subject of constitutional guarantee of values. This is true for all citizens without exception, regardless of their role and place in society.

One of the key functions of any democratic constitution is to guarantee freedom. This shows that freedom in civil society has the highest social value, and guaranteeing freedom by the constitution ensures the autonomous status of citizens and the public organizations created by them. In view of this, F. Hayek argued that there is only one alternative to constitutions: either a free people or a free parliament. Therefore, the norms of the constitution protect both the freedom of civil society in general and the freedom of the individual in particular from the arbitrariness of parliament.

The basis of the rule of law is freedom. The rule of law is represented in the form of a hierarchy of state bodies and institutions created to protect the freedom of citizens. Such a state is an organization that does not absorb its individuals, does not restrict their rights and freedoms. Rights and freedoms are above governmental prerogatives, so the true purpose of power is not to implement messianic ideas, but to provide space for individual growth and development of the individual ${ }^{38}$.

Everyone, except anarchists, understands that absolute freedom is impossible, and it is necessary to regulate people's behavior with the help of laws. But what should be the basis for restricting people's freedom? What should be the boundaries of the state in the lives of citizens? Can the state, with the help of the law, prevent such behavior of an individual, which threatens both the individual and others, society, the state?

The grounds for restricting freedom in modern democratic constitutions are: protection of the foundations of the constitutional order, the rights and legitimate interests of the individual, protection of morals, health, and ensuring the defense of the country and the security of the state.

The Constitution of the Republic of Kazakhstan includes such grounds directly specified in the Constitution (Article 32 of the Constitution) ${ }^{39}$. The Constitution of the Italian Republic Considers such grounds to be contrary to

38 Колісник В. П. Головні пріоритети Конституції України і проблема визначення місця проживання особи. Проблеми законності : pecn. міжвід. наук. зб. I відп. ред. В. Я. Тацій. Х. : Нац. юрид. акад. України, 2008. Вип. 99. 269 с., с. 2.

Конституція Республіки Казахстан URL: https://online.zakon.kz/document/ ?doc_id=1005029\#pos=60;-47 
"good customs". Restriction of personal liberty in any form is not allowed except on the basis of a reasoned act of the judiciary and only in cases and in the manner prescribed by law. (Article 13 of the Constitution) ${ }^{40}$.

The Constitution of the Federal Republic of Germany states that everyone has the right to life and personal integrity, the freedom of the individual is inviolable, and interference with these rights is permitted only by law (Article 2 of the Constitution). Anyone exercising freedom of thought, including freedom of the press (Article 5, paragraph 1), freedom of teaching (Article 5, paragraph 3), freedom of assembly (Article 8), freedom of association (Article 9), secrecy of correspondence, postal and telecommunications (Article 10), the right to property (Article 14) or the right to asylum (Article 16-a) to fight against the foundations of a free democratic order, is deprived of these fundamental rights. Deprivation of these rights and the amount of such deprivation are determined by the Federal Constitutional Court. (Article 18 of the Constitution) ${ }^{41}$. Therefore, deprivation of liberty is possible only on the basis of a court decision and in cases clearly defined by law.

The Constitution of Ukraine threatens the independence of the state, changes in the constitutional order by force, violation of the sovereignty and territorial integrity of the state, undermining its security, illegal seizure of state power, propaganda of war, violence, incitement of interethnic, racial, religious hatred. encroachment on human rights and freedoms, public health - Article 37 of the Constitution of Ukraine. Article 34 of the Basic Law states that the exercise of rights and freedoms may be restricted by law in the interests of national security, territorial integrity or public order in order to prevent riots or crimes, to protect public health, to protect the reputation or rights of others, to prevent disclosure of information obtained in confidence or to maintain the authority and impartiality of justice ${ }^{42}$.

According to I.Yu. Andrievsky, the state must not only ensure human rights and freedoms through law, but also create conditions for security and prosperity. the state, in carrying out coercive measures, must adhere to the same principles as individuals and their associations, in assisting an individual ${ }^{43}$.

Guaranteeing freedom is the goal of any democratic state. Freedom is a universal phenomenon. Freedom in all its dimensions, as an allencompassing concept, means the right to choose one's own priorities in life, to determine one's own way of life, to do everything that is not prohibited by

${ }^{40}$ Конституція Італійської Республіки. URL: https://www.concourt.am/armenian/ legal_resources/world_constitutions/constit/italy/italy--r.htm.

${ }^{4 \overline{1}}$ Конституція Федеративної Республіки Німеччини URL: https://www.concourt.am/armenian/legal_resources/world_constitutions/constit/germany/ german-r.htm.

${ }^{42}$ Конституція України URL: https://zakon.rada.gov.ua/laws/show/254\%D0\%BA/ 96-\%D0\%B2\%D1\%80\#Text.

${ }^{43}$ Тимошенко В. Свобода і необхідність в історії політико-правової думки. Право України. 2006. № 10. С. 26. 
law and at the same time does not prevent others from exercising their own rights. The vast majority of various aspects of freedom are reflected in civil, political, economic, social, cultural and other rights and freedoms. Recognition of freedom as the main constitutional priority and its consolidation as a fundamental principle of the constitutional order is the main task of any civilized democratic state.

Law is the most complete expression of freedom, which enshrines the basic determinants of freedom and promotes its implementation. O.O. Punda pointed out that people are free to the extent of their equality, and are equal to the extent of their freedom ${ }^{44}$. We can speak of two interrelated concepts: "right to liberty" and "freedom in law", which are considered as part and whole, respectively.

The right to freedom is a set of normative-legal constructions of regulation of morally conditioned behavior of an individual (human citizen) in various manifestations of freedom in law.

Freedom of law is a system of opportunities established by society to carry out their own behavior in accordance with the degree of necessity and desire determined by law in a certain period of time provided by the state. According to Article 23 of the Constitution of Ukraine, which enshrines the idea of freedom, everyone is guaranteed the right to free development of his personality, provided that the rights and freedoms of others are not violated. Given this provision of the constitution, a person is allowed to do anything that is not prohibited by law. Thus, freedom in law is expressed through the consolidation of fundamental principles (humanism, democracy, equality) and relevant human rights, among which the right to freedom occupies a prominent place.

Thus, freedom is a value and as important a foundation of the rule of law as equality and justice. Therefore, in our opinion, freedom, first of all, should be considered as a fundamental principle of the state according to which civil society should be formed and the rule of law should be built. Only if freedom is ensured is the development of person as an individual, an individual, and the development of society possible.

\section{CONCLUSIONS}

Thus, the problem of freedom is a problem that has troubled thinkers throughout human history. The main human problem doesn't lose its relevance in our time. This mystery has an unexpected solution, most likely.

The significance of this problem is due to the fact that its solution determines not only the features of the cultural era, but also its further development. It should be noted that the multifaceted, ambiguity and contradictions of the phenomenon of freedom contain objective difficulties in the way of its comprehension and understanding. Society must create such conditions of social and individual life, where all kinds of freedom would take place.

${ }^{44}$ Пунда О. О. Право на свободу: монографія. Х. : Евріка, 2006. 284 с. С. 36. 
Freedom is understood differently in different eras. Human history shows that the challenges of globalization are forcing humanity to rethink the value of the category of "freedom". We observe such a rethinking both on an everyday and scientific level. Always, legal culture will be the connecting link between them. It will play an important role not only in the formation of civil society, but also in the life of the individual and in the history of mankind in general. And it will not depend on the level at which such a process takes place.

The opposite of free people and slaves was determined in antiquity. Slavery emphasized the freedom of free people quite clearly. Freedom was a privilege only a privilege of the few in those days. The ancient Greeks and Romans saw freedom as a natural thing to protect if it was in danger. The idea of freedom dates back to the first century AD for the Jewish people. It embodied the ideal of liberation, rebellion against foreign invaders.

The Jews were the first people who, in the event of enslavement, created an ideology of struggle for national liberation, based on the call for freedom. Christianity is characterized by the idea of freeing the human soul from the all-encompassing dictates of the Old Testament Law. People has free choice, voluntary sacrifice, voluntary responsibility to God.

Christian theology connects the movement of the spirit with freedom in the Middle Ages. The spirit is a movement characterized by impulse and spontaneity. Christian teaching contains a positive concept of freedom. Man would not commit the fall without freedom.

Freedom was understood as an unimpeded disclosure of the abilities of the individual in the Renaissance. At this time there is an update of the notions of civil liberties developed by antiquity. Freedom was interpreted as one of the highest values, as a prerequisite for all natural human rights, in modern times. Scholars such as Thomas Hobbes, Paul Henri Holbach, and others saw freedom as a natural human condition, as well as a path to social equality and justice. German scholars understood Freedom: as inaccessible to sensory cognition, the essence of man (Kant); as the only absolute reality (Johann Gottlieb Fichte); freedom as a multifaceted reality, which in all its manifestations is a form of objectification of the absolute spirit (Georg Wilhelm Friedrich Hegel).

Foreign scholars such as Jean-Jacques Rousseau and Benedict Spinoza, Helvetius and Voltaire, Friedrich Nietzsche and Arthur Schopenhauer, JeanPaul Sarthe and Carl Jaspers made a great contribution to the development of the category of "freedom". Domestic thinkers such as Hryhoriy Skovoroda, Ivan Vyshensky, Panteleimon Kulish, Volodymyr Lypynsky and others made no less important contribution. In view of this, we can say that the term "freedom" is an extremely complex and multifaceted phenomenon.

\section{SUMMARY}

The article reveals the problem of freedom as a value. The article also clarifies the place of the concept of "value" in the theory of legal culture. It is established that in scientific research there is no unambiguous approach to 
the nature and essence of the category of "freedom" as a value. It is proved that without the recognition of the category of individual freedom there can be no question of moral and legal responsibility of a person for his actions. In connection with the above, we would like to note that the idea of freedom is realized through human rights, the precondition of which is.

It was found that human rights were constantly accompanied by the development and attempts to implement the idea of freedom, as the purpose of their creation and implementation in law was to achieve a greater degree of individual freedom. It is established that freedom is a universal value, the source of which is human nature, through the prism of inalienable human rights. Therefore, the problem of freedom is very relevant and requires philosophical and legal understanding.

It was found that the necessary prerequisite for the full meaning of life for the individual and civil society is freedom, free choice, inner harmony. In order for the meaning of life to become a reality, freedom must be combined with the embodiment of a certain value. When a person freely chooses and affirms certain values, his life acquires meaning. Human existence makes sense when the values it chooses are worthy of man and recognized by society. This is the basis for the conclusion that values in unity with freedom determine the meaning of human life. Thus, freedom is a philosophical and legal value, the source of which is a person who is able to make their choices and take responsibility for its consequences, choose their goals and means to achieve them.

\section{REFERENCES}

1. Бровко Н.I. Філософсько-правовий аналіз категорії свободи та відповідальності людини. Філософські та методологічні проблеми права, № 1. 2014 C. 54-57. URL : http://elar.naiau.kiev.ua/jspui/ bitstream/123456789/933/1/8.pdf.

2. Гоббс Т. Соч. в 2-х тт. М.,1991.T.2, с.163,164.

3. Данильян О.Г., Тараненко В.М. Основи філософії. Проблема свободи і відповідальності людини URL: http://library.nlu.edu.ua/ POLN_TEXT/4\%20KURS/4/1/13H3R13_3.htm.

4. Гуторович O.В. Проблема свободы и её решение в античной философии. URL: https://www.gramota.net/articles/issn_1997292X_2015_7-1_09.pdf C. 36.

5. Качур В.О. До визначення поняття «правова культура» у правознавстві. Право. Людина. Довкілля : науково-практичний журнал. 2019. № 10(1). C. 17-18. DOI: http://dx.doi.org/10.31548/law2019.01.002.

6. Kachur, V., Protosavitska, L., Zasukha, L., GolovkoL. (2020). The Role of Legal Culture in Maintaining Social Stability and Countering Separatist Movements: Case of Ukraine. European Journal of sustainable development, Volume9, № 1, 294-299.

7. Качур В. ПротосавіцькаЛ. (2020) Місце категорії «цінність»у теорії правової культури. Modern achievements ofEU countries and 
Ukraine in the area of law: Collective monograph. Riga: Izdevniecíba "Baltija Publishing", 2020. P. 1. 632 p. P. 225

8. Кант И. Критика чистого разума. СПб., 1993, с. 449-456.

9. Кисельов C.O. Проблема свободи у спадщины Платона URL: http://ekmair.ukma.edu.ua/bitstream/handle/123456789/6126/Kysel\%27ov_ Problema_svobody_u_spadshchyni_Platona.PDF

10. Лосский В. Очерк мистического богословия Восточной Церкви. В кн.: Мистическое богословие. Киев, 1991. с. 176.

11. Лях В. Соціальні, особистісні та екзистенційні виміри свободи. Мультиверсум. Філософський альманах. К., 2004. № 44. С. 1-14.

12. Майданюк I. Свобода як цінність права у філософській спадщині Станіслава Оріховського. URL : https://ela.kpi.ua/bitstream/123456789/ 11136/4/08.pdf.

13. Петренко М.О. Філософія свободи в контексті проблеми людської гідності Науковий вісник. Серія «Філософія». Харків: ХНПУ, 2017. Вип. 49. С. 142-156. С. 151.

14. Попович М.В. «Свобода від» і «свобода для» Проблеми сутності свободи: методологічні та соичіальні виміри. Матеріали Науковотеоретичної конференції 26 жовтня 2007 року. К., 2007. С. 3-8 С. 4.

15. Прохоров К. Тайна предопределения URL: https://royallib.com/book/prohorov_konstantin/tayna_predopredeleniya.html

16. РідельМ. Свобода та відповідальність. Два основних поняття комунікативної етики. Першоджерела комунікативної філософії. К., 1996. С. 68-84.

17. Ситниченко Л.А. Стратегії свободи в сучасній соціальній та практичній філософії / Л.А.Ситниченко Свобода: сучасні виміри та альтернативи. К. : Укр. Центр духовн. культури, 2004. 316 с.

18. Словарь античности/пер. с нем. М.: Прогресс, 1989. 704 с.

19. Спіноза. Етика. URL: http://loveread.ec/read_book.php?id= $90717 \& p=67 \# g 1 \_23$ c. 67.

20. Філософія права : підруч. для студ. юрид. вищ. навч. закл / Свобода як цінність. Право як форма свободи. URL: https://fil.wikireading.ru/52706.

21. Христианство. Энциклопедический словарь. В 3-х тт. М., 1993-1995. T. 2., C. 523.

22. Шопенгауэр А. О свободе воли. Калининград, 2001, с. 255.

23. Загальна Декларація прав людини : $\mathrm{OOH}$; Декларація, Міжнародний документ від 10.12 .1948 p. URL : http://zakon2.rada.gov.ua.

24. Конституционное право зарубежных стран : учеб. для вузов / под общ. ред. М.В. Баглая, Ю.И. Лейбо, Л.М. Энтина. 2-е изд., перераб. М. : Норма, 2004. $832 \mathrm{c}$.

25. Мальцев В.А. Право как нормативно-деятельная система. Изд.вузов. Правоведение. 2003. № 2. 180 с., с. 19. 
26. Конституція Польської республіки від 2 квітня 1997 URL: https://www.concourt.am/armenian/legal_resources/world_constitutions/con stit/poland/poland-r.htm

27. Колісник В.П. Головні пріоритети Конституції України i проблема визначення місця проживання особи. Проблеми законності : респ. міжвід. наук. зб. / відп. ред. В. Я. Тацій. Х. : Нац. юрид. акад. України, 2008. Вип. 99. 269 с.

28. Конституція Республіки Казахстан. URL: https://online.zakon.kz/ document/?doc_id=1005029\#pos=60;-47.

29. Конституція Італійської

Республіки. URL: https://www.concourt.am/armenian/legal_resources/world_constitutions/con stit/italy/italy--r.htm.

30. Конституція Федеративної Республіки Німеччини. URL: https://www.concourt.am/armenian/legal_resources/world_constitutions/con stit/germany/german-r.htm.

31. Конституція України. URL: https://zakon.rada.gov.ua/laws/ show/254\%D0\%BA/96-\%D0\%B2\%D1\%80\#Text

32. Тимошенко В. Свобода і необхідність в історії політико-правової думки. Право Украӥни. 2006. №10. С. 24-28.

33. Пунда О. О. Право на свободу : монографія. Х. : Евріка, 2006. 284 c.

\section{Information about the author: \\ Protosavitska Liudmyla Stepanivna,}

Candidate of Historical Sciences, Associate Professor, Associate Professor at the Department of State and Law National University of Life and Environmental Sciences of Ukraine 17, Vasylkivska str., Kyiv, 03040, Ukraine 